\title{
Uloga i značaj kompanija u oblikovanju i funkcionisanju inovacionog sistema
}

\author{
Zijada Rahimić*
}

\begin{abstract}
Apstrakt: Kontinuiranim jačanjem istraživačko razvojnih aktivnosti i inovativnih sposobnosti kompanije postižu dugoročno održive konkurentske prednosti na sve kompleksnijim i neizvjesnijim tržištima današnjice. Istovremeno, stvaranjem novog znanja, inovativnom primjenom postojećih znanja i tehnologija, te olakšavanjem njihovog transfera doprinose izgradnji ekonomije znanja i konkurentnosti zemlje. Jedan od stubova ekonomije znanja jeste efektivan inovacioni sistem, u kojem posebno mjesto i ulogu imaju kompanije. Cilj rada je predstaviti i analizirati doprinos kompanija efikasnom funkcionisanju inovacionih sistema, ispitati vezu i uticaj inovativnosti i izdataka za istraživanje i razvoj na globalnu konkurentnost. Kao metodološki okvir za analizu efekata inovacijskih sposobnosti korišten je Globalni indeks inovacija (GII), kao i Indeks globalne konkurentnosti (GCI), u kojem inovacije i sofisticiranost predstavljaju jednu od tri kategorije konkurentnosti. U fokusu analize bio je odnos između inovacijskih inputa i inovacijskih outputa, kao i odnos između GII i GCI Bosne i Hercegovine, zemalja zapadnog Balkana i grupe odabranih zemalja Evropske unije (EU). Rezultati istraživanja pokazuju da postoji statistički signifikantna veza između inovacijskih inputa i outputa. Evidentne su razlike u jačini veze između varijabli inovativnosti i konkurentnosti za zemlje zapadnog Balkana i za izabrane zemlje članice EU. Takođe je utvrđeno da izdaci za istraživanje i razvoj značajno utiču na vrijednost indeksa konkurentnosti.
\end{abstract}

Ključne riječi: inovacioni sistem, ekonomija znanja, istraživanje i razvoj, globalni indeks inovacija, indeks globalne konkurentnosti

\section{Uvod}

U današnjem dinamičnom, neizvjesnom okruženju kojeg karakteriše globalizacija, iznimno brz razvoj informaciono-komunikacionih tehnologija, te sve brže zastarjevanje znanja za izgradnju i očuvanje konkurentske pozicije posebno bitni su znanje i inovacije. U savremenoj ekonomiji znanje i inovacije predstavljaju ključne faktore dugoročno održivog opstanka i razvoja preduzeća. ${ }^{1}$ Generisanje i upotreba znanja igra ključnu ulogu u stvaranju nacionalnog

\footnotetext{
*Prof. dr., Ekonomski fakultet Univerziteta u Sarajevu. E-mail: zijada.rahimic@efsa.unsa.ba ${ }^{1}$ Jovičić J. i Petković S. (2016). Inovacije kao faktor konkurentnosti privrede s osvrtom na Bosnu i Hercegovinu. Obrazovanje za preduzetništvo, 6(1), 2016, str. 102.
} 
bogatstva u ekonomijama baziranim na znanju, koje predstavljaju modernu paradigmu konkurentnosti nacionalnih privreda. U tom smislu svrha ovog rada je ukazati na značaj inovativnih sposobnosti i istraživačko-razvojnih aktivnosti kompanija za postizanje njihovih konkurentskih prednosti, za izgradnju i funkcionisanje inovacionih sistema i jačanje konkurentnosti nacionalne privrede. Predmet istraživanja su koncepti inovacionih sistema, te načini mjerenja inovacijskih performansi i konkurentnosti. Cilj rada je usmjeren na predstavljanje i analizu doprinosa kompanija funkcionisanju inovacionih sistema, na ispitivanje odnosa između inovacijskih inputa i outputa, inovativnosti i globalne konkurentnosti, kao i jačine uticaja izdataka za istraživanje $i$ razvoj (IiR) na konkurentnost privrede.

Slijedom definisanog predmeta i postavljenih ciljeva istraživanja rad je strukturiran tako da su nakon Uvoda predstavljene karakteristike i značaj inovacija i inovacionih sistema kao jednog od stubova ekonomije zasnovane na znanju u postizanju konkurentskih prednosti. Posebna pažnja u ovom, drugom dijelu rada je usmjerena na ulogu kompanija u funkcionisanju inovacionih sistema. Potom su navedeni različiti indeksi, kojima se nastoje prikazati i uporediti rezultati inovativnosti i globalne konkurentnosti privrede ${ }^{2}$ sa fokusom na prikaz globalnog indeksa inovacija (GII) i indeksa globalne konkurentnosti (GCI). Primjenom navedenih indeksa provedeno je empirijsko istraživanje i predstavljeni rezultati analize za BiH, zemlje zapadnog Balkana i izabrane zemlje EU. Na kraju, u zaključku predstavljene su osnovne spoznaje na temelju rezultata teorijskog i empirijskog istraživanja, te je naglašen značaj kompanija za efektivno i efikasno funkcionisanje inovacionih sistema.

\section{Inovacioni sistem kao jedan od stubova ekonomije znanja}

Stalne promjene, kao ključna karakteristika današnjeg okruženja ogledaju se između ostalog i u prelasku klasične industrijske u tehnološku eru, odnosno u činjenici da su industrije koje počivaju na prirodnim bogatstvima zamijenjene sa tzv. „brainpower“ industrijama. Najrazvijenije zemlje današnjice svoj uspjeh su ostvarile upravo prelaskom sa kapitalom intenzivne na znanjem intenzivnu ekonomiju. ${ }^{3}$ Ključnu ulogu u stvaranju nacionalnog bogatstva u tim ekonomijama

\footnotetext{
${ }^{2}$ Dossou Y.L. i Khvatova T.Y. (2020). Analysis of innovative activity of companies in developing countries on the example of West African countries. St. Petersburg State Polytechnical University Journal.Economics, 13 (1).

${ }^{3}$ Rahimić Z. i Kožo A. (2009). Building and Development of the Knowledge Based Economy in Bosnia and Herzegovina. Journal of Interdisciplinary Management Research, Vol. V, Ja-
} 
ima generisanje, diseminacija i efektivna upotreba znanja. Stoga je ekonomija zasnovana na znanju postala dominantna ekonomija dvadeset i prvog stoljeća.

Kao stubovi ekonomije zasnovane na znanju navode se: ljudski resursi, moderna i adekvatna informatička infrastruktura, efektivan inovacioni sistem i institucionalni režim. Inovacioni sistem u širem smislu predstavlja funkcionalnu cjelinu svih javnih i privatnih subjekata i institucija koje neposredno učestvuju u stvaranju novog znanja fundamentalnim, primijenjenim i razvojnim istraživanjima, inovativnom primjenom postojećih znanja i tehnologija te olakšavanjem njihovog transfera unutar države i u međunarodnoj razmjeni. ${ }^{4} \mathrm{U}$ kontekstu ekonomije znanja bitno je ukazati na postojanje djelimične podudarnosti i funkcionalne komplementarnosti između sistema nauke s jedne strane te uže shvaćenog inovacionog sistema s druge strane, tako da se ovi termini koriste i kao sinonimi. ${ }^{5}$

Imajući u vidu predmet istraživanja, u nastavku će se detaljno objasniti karakteristike i značaj inovacija i inovacionih sistema u izgradnji konkurentnosti privrede, kao i uloga kompanija u funkcionisanju inovacionog sistema, te će se predstaviti najvažniji pokazatelji inovativnosti i konkurentnosti privrede.

\subsection{Značaj inovacija i inovacionih sistema u postizanju konkurentnosti privrede}

Inovacije i inovacioni sistemi postaju sve zanimljiviji kreatorima politika za postizanje ekonomskih i socijalnih ciljeva. Inovacija je stavljena u središte strategije Evropske unije jer pruža ,najbolje sredstvo za uspješno rješavanje glavnih društvenih izazova“" (Evropska komisija, 2010). ${ }^{6}$ Također se u novije vrijeme ističe da su istraživanje, inovacije i obrazovanje presudni za Evropu pri prelasku ka klimatskoj neutralnosti i digitalnom vodstvu. Evropska industrija, ekonomija i društvo mijenjaju se brzinom svjetlosti, što predstavlja jedinstvenu priliku za pretvaranje EU u pošteno i prosperitetno društvo, sa modernom, resursno efikasnom i konkurentnom ekonomijom koja radi za ljude. ${ }^{7}$

\footnotetext{
nuary 2009 , str. 112.

${ }^{4}$ Trifković M. (2020). Harmonizacija sistema nauke u Bosni i Hercegovini. Akademija nauka i umjetnosti Bosne i Hercegovine, Centar za sistemska istraživanja, knjiga 5/1, posebna izdanja, Sarajevo, str. 34.

${ }^{5}$ Trifković M. (2020). str. 40.

${ }^{6}$ Schrempf B., Kaplan D. i Schroeder D. (2013). National, Regional, and Sectoral Systems of Innovation-An overview. Report for FP7 Project "Progress". European Comission, str. 3. ${ }^{7}$ European Commision (2020). Science, research and Innovation Performance of the EU 2020, A fair, green and digital Europe. Publication Office of the European Union. Luxem-
} 
Najčešće se pojam inovacija veže za tehnološke izmjene, koje uključuju nov ili inovirani način rada ili proizvodnje postojećih proizvoda ili pak proizvodnju sasvim novih proizvoda. Ipak, sve izmjene i sva poboljšanja u okviru jednog preduzeća ali i u ostalim sferama života mogu se obuhvatiti pojmom inovacija.

Najpouzdanijim izvorom inovacija smatra se znanje temeljeno na istraživanju i razvoju. Međutim, izuzetno važni su i drugi načini sticanja i akumuliranja znanja poput "učenja radom" i "učenja korištenjem". Perspektiva prakse konceptualizira inovacije smještene u svakodnevnim aktivnostima organiziranja, učenja i rada. Ljudi stvaraju nova znanja dok rade na rješavanju problema s kojima se suočavaju u praksi. Drugim riječima, znanje, rad i inovacije su isprepleteni. U ekonomiji znanja, stvaranje baze znanja zavisi od sinergija ostvarenih između tri glavna aktera u ekonomiji: akademske, poslovne zajednice i vlade.

Inovacije postaju sve značajniji faktor u borbi za očuvanje i poboljšanje konkurentske pozicije preduzeća na domaćem i internacionalnom tržištu. ${ }^{8} \mathrm{U}$ globalnom ekonomskom kontekstu, inovacije su postale temeljni i odlučujući stub razvoja zemlje i njenog potencijalnog uspjeha. Preciznije rečeno, inovacije predstavljaju instrument ekonomske sigurnosti države i faktor poboljšanja međunarodne konkurentnosti. ${ }^{9}$ Pozitivna korelacija između inovacija i privrednog razvoja potvrđena je u brojnim empirijskim i teorijskim istraživanjima, ${ }^{10}$ te je ukazano da povećane inovacijske sposobnosti mogu dovesti do značajnog industrijskog razvoja i razvoja društva općenito. ${ }^{11}$

Povećana svijest o važnosti inovacija za privredni rast rezultirala je razvojem koncepta nacionalnog inovacionog sistema. Posebne zasluge za razvoj ovog koncepta pripisuju se britanskom ekonomisti Christopheru Freemanu, koji nacionalni inovacioni sistem (NIS) definiše kao mrežu institucija privatnog i javnog sektora koje međusobnim interakcijama iniciraju, uvoze,

bourg. https://ec.europa.eu/info/publications/science-research-and-innovation-performanceeu-2020_en

${ }^{8}$ Rahimić Z. (2006). Izgradnja konkurentskih prednosti preduzeća kroz njegova strateška opredjeljenja. Ekonomski fakultet u Sarajevu, str. 275.

${ }^{9}$ Chuvakhina L.G., Terskaya G.A. i Buevich S.Y. (2018). Innovations as a factor of state's improved performance in the World Economic System. Revista Espacios, Vol. 39 (\# 04) Year 2018.

${ }^{10}$ Kaynak S., Altuntas S. i Dereli T. (2017). Comparing the innovation performance of EU candidate countries: an entropy-based TOPSIS approach. Economic Research-Ekonomska Istraživanja, 30:1, 31-54.

${ }^{11}$ Yongabo P. i Göransson B. (2020). Constructing the national innovation system in Rwanda: efforts and challenges, Innovation and Development. DOI:10.1080/2157930X.2020.1846886 
modifikuju i šire inovacije. ${ }^{12}$ NIS se može posmatrati kao društveno-ekonomski sistem u kojem komuniciraju različiti akteri, poput kompanija, istraživačkih i akademskih organizacija, javne uprave, profesionalnih posrednika i drugih formalnih i neformalnih institucija. NIS koristi sve raspoložive resurse u zemlji, tj. ljudske, finansijske, infrastrukturne i institucionalne resurse. Nacionalni inovacioni sistem se također može smatrati nematerijalnom imovinom ${ }^{13}$ koja doprinosi privrednom rastu zemlje, stvaranju vrijednosti i blagostanju.

Koncept nacionalnih inovacionih sistema zasniva se na pretpostavci da privredni rast zemlje, kao rezultat tehnološkog napretka, ne zavisi toliko od veličine istraživačko-razvojnih resursa, koliko od načina organizovanja i upravljanja tim resursima na nacionalnom nivou. Ovakav stav posebno je bitan za male zemlje i za zemlje u razvoju, koje po pravilu ne raspolažu značajnim inovacionim kapacitetom. ${ }^{14}$ Stoga treba temeljito ispitati nacionalni inovacioni sistem u kontekstu zemalja u razvoju ${ }^{15}$ uzimajući u obzir kapacitet proizvodnje znanja kao i apsorpcijski kapacitet krajnjih korisnika, te ulogu inovacijskih politika.

Koncept efikasnosti nacionalnog inovacionog sistema direktno je povezan s konceptom produktivnosti. Smatra se da je inovacioni sistem efikasan kada s jednakom količinom inovativnih inputa generira više inovacijskih rezultata, odnosno kada je potrebno manje inputa da bi se stvorila ista količina inovacija. ${ }^{16}$

Priručnik iz Osla (Oslo Manual OECD, 2005.) identificira četiri faktora koja utiču na efikasnost inovacijskog procesa: okvirni uslovi, institucije

\footnotetext{
${ }^{12}$ Freeman, C. (1995). The "National System of Innovation" in historical perspective. Cambridge Journal of Economics, 19 (1) 5-24, preuzeto iz Cvetanovic D., Cvetanović S. i Bogić D. (2020).

${ }^{13}$ Gogodze J. (2016). Mechanisms and Functions within a National Innovation System. Journal of Technology Management\&Innovation, Universidad Alberto Hurtado, Facultad de Economía y Negocios. Volume 11, Issue 4, str. 12-21.

${ }^{14}$ Cvetanovic D., Cvetanović S. i Bogić D. (2020). Rastući značaj koncepta regionalnih inovacionih sistema za ekonomski i društveni razvoj.

https://konferencija.komorapirot.com/44.RASTUCI\%20ZNACAJ\%20KONCEPTA $\% 20$ REGIONALNIH\%20INOVACIONIH\%20SISTEMA\%20ZA\%20EKONOMSKI\%20I\%20 DRUSTVENI\%20RAZVOJ.pdf

${ }^{15}$ Yongabo P. i Göransson B (2020). Constructing the national innovation system in Rwanda: efforts and challenges. Innovation and Development, DOI:10.1080/2157930X.2020.1846886 ${ }^{16}$ Jankowska B., Matysek-Jędrych A. i Mroczek-Dąbrowska K. (2017). Efficiency of national innovation systems: Poland and Bulgaria in the context of the Global Innovation Index. Comparative Economic Research, De Gruyter, Warsaw, Vol. 20, Iss. 3, pp. 77-94.
} 
za nauku i tehnologiju, mehanizmi prenosa i inovativni pogoni specifični za kompanije. Opšti okvirni uslovi oblikuju aktivnosti preduzeća i njihovu sposobnost obavljanja inovativnih aktivnosti. Efikasnost institucija za nauku i tehnologiju pokreće akumulaciju znanja. Mehanizmi prenosa poboljšavaju protok informacija i vještina između zainteresiranih strana i osiguravaju da inovativne ideje dospiju na tržište. Konačno, same kompanije trebaju identificirati i koristiti potencijal za inovacije kako bi ojačale inovacijski proces. Predstavljeni faktori odgovaraju određenim oblastima interventnih politika. Od vlade se očekuje da kreira mjere za rješavanje potencijalnih prepreka i postavi prioritete. ${ }^{17}$ Inače, smatra se da je država najuticajniji faktor u većini nacionalnih inovacionih sistema, pošto finansira veći dio osnovnih istraživačkih i razvojnih aktivnosti u zemlji. ${ }^{18}$

Pored navedenih faktora, istorijsko nasljeđe može imati dubok uticaj na oblik nacionalnih inovacionih sistema. ${ }^{19}$ Doista su istorijski događaji i društvene norme u svakoj zemlji imali veliki uticaj na oblik institucija, artikulaciju prioriteta i rezultate inovacija. Ipak, zahvaljujući trendu kontinuiranog učenja razlike između nacionalnih inovacionih sistema uočene u prethodnim decenijama danas su manje očite. ${ }^{20}$ Primjera radi, inovacioni sistem Japana zasnovan je na "alternativnoj energetskoj tehnologiji" ili energetskoj efikasnosti, a u Sjedinjenim Američkim Državama dominirajući koncept je "inovacioni ekosistem".

Inovacioni sistemi mogu funkcionisati na nacionalnom, regionalnom ili međunarodnom nivou. Bez obzira na nivo, dimenziju posmatranja inovacionog sistema naglašava se značaj proizvodnje i korištenja novih znanja $u$ stvaranju vrijednosti. ${ }^{21} \mathrm{U}$ procesu proizvodnje i širenja znanja posebno bitnim

\footnotetext{
${ }^{17}$ OECD (2013). Triple Helix partnerstva za inovacije u Bosni i Hercegovini. Razvoj privatnog sektora - Priručnik za politike. Sarajevo, str. 17. i OECD (2005). Oslo Manual: Guidelines for collecting and interpreting innovation data, 3. izdanje, OECD, Pariz.

${ }^{18}$ Melaas A. i Zhang F. (2016). National Innovation Systems in the United States and China A Brief Review of the Literature. The Center for International Environment\&Resource Policy, Tufs University. Medford.

${ }^{19}$ Radošević S. (2002). Regional innovation systems in Central and Eastern Europe: Determinants, organizers and alignments. The Journal of Technology Transfer, 27, 87-96. Preuzeto iz: Mosurović Ružičić M., Miletić M. i Dobrota, M. (2021). Does a National Innovation System Encourage Sustainability? Lessons from the Construction Industry in Serbia. Sustainability 2021, 13, 3591, str. 5.

${ }^{20}$ Fatma A. (2018). Overview of the Japanese Innovation Systems vs. the American Innovation System. Journal of Global Economics, 6: 312. doi:10.4172/2375-4389.1000312

${ }^{21}$ Schrempf B., Kaplan D. i Schroeder D. (2013). National, Regional, and Sectoral Systems of Innovation-An overview. Report for FP7 Project "Progress". European Comission.
} 
smatra se angažman svih aktera, povjerenje i odanost među akterima i podržavajuće okruženje. ${ }^{22}$

\subsection{Uloga kompanija u funkcionisanju inovacionog sistema}

Početno istraživanje nacionalnih inovacionih sistema, ranih 1990-ih je imalo za cilj izmjeriti inovacijske rezultate kompanija kroz razvoj novih proizvoda, kao i njihovu sposobnost apsorpcije inovativnih tehnologija. ${ }^{23}$ Upravo u tom periodu, krajem 20. stoljeća zbog sve veće neizvjesnosti i turbulentnosti promjena u okruženju, uspjeh preduzeća se zasnivao na inovativnoj sposobnosti, za razliku od 60-ih godina kada je cilj preduzeća bio usmjeren na povećanje obima proizvodnje, ili 70-ih godina na snižavanje troškova proizvodnje, te 80-ih godina na postizanje visokog kvaliteta. Inovativne sposobnosti kompanija doprinose kako postizanju i očuvanju njihovih konkurentskih prednosti, tako i konkurentnosti zemlje.

Polazeći od činjenice da će se dinamika tržišta i tržišna neizvjesnost u budućnosti povećati može se reći da preduzeća trebaju nastojati da jačaju svoju istraživačko razvojnu aktivnost, odnosno da jačaju inovativne sposobnosti. Istraživačko-razvojna aktivnost jednog preduzeća zavisi ne samo od sposobnosti, kojima raspolaže to preduzeće nego i od faktora iz eksternog okruženja. Među njima se posebno ističu stav vlade (države) prema naučno istraživačkoj djelatnosti, snažna veza između naučno-istraživačkih institucija (univerziteta i instituta) sa privrednim subjektima, brzina tehnološkog transfera i stopa zastarjevanja tehnologija, što je vezano za vrstu djelatnosti preduzeća. Stoga su se novija istraživanja koncentrirala na specifične uloge drugih aktera $u$ okviru inovacionog sistema, poput uloge vlade u stvaranju poticaja i uloga univerziteta u provođenju istraživanja. ${ }^{24} \mathrm{~S}$ tim u vezi, interesantno je navesti da EU podržava istraživanje i inovacije u industriji, jer dvije trećine ulaganja u istraživanje i razvoj privatnog sektora generira $80 \%$ izvoza iz EU. ${ }^{25}$

\footnotetext{
${ }^{22}$ Chaminade, C. i Lundvall B. (2019). Science, Technology, and Innovation Policy:Old Patterns and New Challenges. Oxford University Press. Oxford.

${ }^{23}$ Melaas A. i Zhang F. (2016). National Innovation Systems in the United States and China A Brief Review of the Literature. The Center for International Environment\&Resource Policy, Tufs University. Medford.

${ }^{24}$ Melaas A. i Zhang F. (2016). str. 3.

25 https://ec.europa.eu/info/research-and-innovation/research-area/industrial-research-andinnovation_en
} 
Konceptualni model odnosa industrije i nauke (Conceptual Model for Analysing Industry-Science Relations ${ }^{26}$ smatra se alatom za podizanje konkurentnosti i tehnoloških performansi preduzeća korištenjem znanja dostupnih u javnim istraživanjima. Cilj promocije odnosa industrije i nauke je osigurati da se javna ulaganja u visoko obrazovanje prelijevaju na preduzeća i čine ta ulaganja ekonomski produktivnim. Model odnosa industrije i nauke se smatra rezultatom aktivnosti aktera na "tržištu znanja", kojeg karakteriše visoka asimetrija informacija između učesnika i niska transparentnost tržišta, visoki transakcijski troškovi razmjene znanja, ograničenja za finansiranje proizvodnje i razmjene znanja zbog finansijskih tržišta nesklonih riziku i kratkoročnih orijentacija. Na performanse odnosa industrije i nauke utiču u prvom redu karakteristike glavnih aktera (preduzeća i javnih naučnih ustanova) kroz potražnju i ponudu na nacionalnom tržištu znanja, drugo, okvirni uslovi poput infrastrukture, zakonodavstva i propisa i institucionalnih postavki, i treće intenzitet međusobne komunikacije industrije i nauke.

Inovativnost se može podstaknuti primjenom modela trostruke spirale, $\mathrm{tj}$. saradnjom između akademske i poslovne zajednice te lokalne vlade, odnosno tzv. Triple Helix modela (trostruke spirale) ${ }^{27}$ Koordinacijom aktivnosti sve tri zainteresirane strane i efikasnom komunikacijom omogućava se postizanje sinergetskih efekata i stvaranje veće vrijednosti. ${ }^{28} \mathrm{U}$ teoriji i praksi postoji više modela stvaranja znanja i inovacione kreativnosti. Tako je Četvorostruki Heliks model baziran na Triple Heliks modelu i kao četvrtu spiralu dodaje društvo bazirano na kulturi i medijima i civilno društvo. Četvrti heliks se povezuje sa medijima, kreativnom industrijom, kulturom, vrijednostima, stilom života i umjetnošću. Petostruki Quintuple Heliks dodaje kao petu spiralu prirodno okruženje ili životnu sredinu, a Quintuple Heliks može biti predložen kao okvir za transdisciplinarnu (i interdisciplinarnu) analizu održivog razvoja i socijalne ekologije. ${ }^{29}$

\footnotetext{
${ }^{26}$ Polt W., Rammer Ch., Schartinger D., Gassler H. i Schibany A. (2001). Benchmarking Industry-Science Relations in Europe - the Role of Framework Conditions. Science and Public Policy 28 (4), August 2001, pages 247-258.

${ }^{27}$ Leydesdorff L. i Strand Ø. (2013). The Swedish System of Innovation: Regional Synergies in a Knowledge-Based Economy. Journal of the American Society for Information Science and Technology. DOI: 10.1002/asi.22895

${ }^{28}$ OECD (2013). Triple Helix partnerstva za inovacije u Bosni i Hercegovini. Razvoj privatnog sektora - Priručnik za politike. Sarajevo, str. 17. i OECD (2005.), Oslo Manual: Guidelines for collecting and interpreting innovation data, 3. izdanje, OECD, Pariz.

${ }^{29}$ Ješić J. (2015). Model četverostruke spirale (Quadruple Helix Model) kao osnova nacionalnog inovacionog sistema, doktorska teza. Univerzitet Edukons Fakultet poslovne ekonomije Sremska Kamenica, Novi Sad.
} 
Poseban naglasak u procesu stvaranja inovacija stavlja se na fenomen industrijskih klastera, koji doprinose kvaliteti poslovnog okruženja i predstavljaju važan faktor poboljšanja konkurentnosti. ${ }^{30} \mathrm{U}$ literaturi se ,industrijski klasteri“ zajedno sa konceptima, „,inovativni miljei“ i „samoučeće regije ${ }^{\text {311 }}$ mogu naći pod zajedničkim nazivom prostornih inovacionih sistema. Prostorni inovacioni sistemi ${ }^{32}$ obuhvataju međusobno povezana preduzeća $\mathrm{u}$ određenim sektorima, zajedno s odgovarajućim dobavljačima i uslužnim sektorom, kao i niz pratećih institucija, uključujući univerzitete, institute, laboratorije, profesionalna udruženja i agencije. Ovo je posebno bitno za mala preduzeća, jer imaju manje resursa i mogućnosti za interna vlastita istraživanja. Zahvaljujući interakciji sa drugim institucijama malim i mikro kompanijama je olakšan pristup novim znanjima, koja postaju izvor za njihove inovacije. ${ }^{33}$

Postojeće temelje saradnje u okviru inovacionog sistema moguće je nadopuniti zagovaranjem kulture otvaranja naučnih i inovacijskih procesa, tj. otvorenim inovacijama (open innovation) i otvorenom naukom (open science). ${ }^{34}$ Nova paradigma otvorenosti neće zamijeniti postojeće temelje saradnje, nego će ih nadopuniti što će omogućiti kompanijama da se lakše i brže transformišu u kompanije koje kreiraju znanje (Knowledge-Creating Company) ${ }^{35}$ i učeće organizacije (Learning Organizations). Takvim poslovnim pristupom i strateškim opredjeljenjem navedene kompanije uspijevaju da izgrade dugoročno održivu konkurentsku prednost, intenziviraju saradnju sa univerzitetima, te doprinose efikasnosti inovacionih sistema, bržem privrednom rastu i konkurentnosti zemlje.

\footnotetext{
${ }^{30}$ Porter M. i Stern, S. (2002). National innovative capacity. In K. Scwab, M. Porter, \& J. Sachs (Eds.), The global competitiveness report 2001-2002, 102-118. Oxford University Press. New York.

${ }^{31}$ Puljiz, J. (2009). Faktori regionalnog razvoja i regionalnih nejednakosti u Republici Hrvatskoj. Doktorska disertacija. Ekonomski fakultet, Sveučilište u Splitu. Split, str. 40.

${ }^{32}$ Despotović D. i Cvetanović S. (2017). The theoretical explication of the factors of regional growth and the economic convergence (divergence) of the region. Economic Horizons, May - August 2017, Volume 19, Number 2, 111 - 125.

${ }^{33}$ Rigg C., Coughlan P., O'Leary D. i Coghlan D. (2021). A practice perspective on knowledge, learning and innovation - insights from an EU network of small food producers. Entrepreneurship \& Regional Development.

${ }^{34}$ Hetze P. i Meyer M. (2018). Was bringt die Oeffnung von Wissenschaft und Innovation? Stifterverband Bildung. Wissenschaft. Innovation, Berlin i Warnke P. et al. (2016). Opening up the innovation system framework towards new actors and institutions. Fraunhofer ISI Discussion Papers - Innovation Systems and Policy Analysis, No. 49, Fraunhofer ISI, Karlsruhe. ${ }^{35}$ Vukotić S., Zakić N. i Ćurčić N. (2017). Menadžment znanja i upravljanje inovacijama kao izvor poslovnog uspeha i konkurentske predosti preduzeća. Četvrti naučno-stručni skup POLITEHNIKA 2017, str. 436-442.
} 


\subsection{Pokazatelji inovativnosti privrede}

Danas smo svjedoci eksplozije istraživanja kojima se pokušavaju prikazati i uporediti rezultati inovacija u najširem smislu. ${ }^{36}$ Razne organizacije i istraživači razvili su niz složenih pokazatelja za mjerenje inovacija na nivou države. ${ }^{37}$ Najsveobuhvatniji uvid u inovacijski kapacitet i inovacijske performanse pojedine zemlje daju: 1. Globalni indeks inovacija (GII-Global Innovation Index), 2. Bloombergov indeks inovacija (Bloomberg Innovation Index), te 3. Evropska ljestvica inovativnosti (European Innovation Scoreboard). Pored navedenih indeksa koji su isključivo fokusirani na inovacije, postoje indeksi koji se bave širim temama poput konkurentnosti, ali dijelom i inovacijama, npr. Indeks globalne konkurentnosti (GCI-Global Competitiveness Index). Rezultati ispitivanja sadržaja ${ }^{38}$ Indeksa globalne konkurentnosti, Indeksa humanog razvoja, Indeksa ekonomije znanja, Evropske ljestvice inovativnosti ukazuju da ovi indeksi pružaju vrlo slične informacije. ${ }^{39} \mathrm{U}$ nastavku će se dati kratki opis specifičnosti dva indexa, koji su korišteni u empirijskom istraživanju i to: globalni indeks inovacija (GII) i indeks globalne konkurentnosti (GCI).

Globalni indeks inovacija je kreiran u saradnji dviju poslovnih škola "Cornell -SC Johnson College of Business" i "INSEAD -The Business School for the world" i UN-ove organizacije za intelektualno vlasništvo "WIPO -World Intellectual Property Organization". Prepoznajući ključnu ulogu inovacija kao pokretača privrednog rasta i prosperiteta, GII uključuje pokazatelje koji nadilaze tradicionalna mjerenja inovacija. Ovaj indeks je povezao ekonomske indikatore koji utiču na inovativnost zemlje objedinjujući ih u određeni okvir.

Analiza inovacijske aktivnosti prema GII je sastavljena od sedam stubova inovativnosti grupisanih u dva podindeksa: inovacijski input (III-Innovation Input Index) i inovacijski output (IOI-Innovation Output Index). ${ }^{40}$ Inovacijski

\footnotetext{
${ }^{36}$ Adam F. (2014). Measuring National InnovationPerformance - the Innovation Union Scoreboard Revisited. Springer. Berlin, Heidelberg.

${ }^{37}$ Gogodze J. (2016). Mechanisms and Functions within a National Innovation System. Journal of Technology Management \& Innovation (C) Universidad Alberto Hurtado, Facultad de Economía y Negocios. Volume 11, Issue 4, str. 12.

${ }^{38}$ Wojciech N. (2016). Composite Indexes Economic and Social Performance: Do They Provide Valuable Information. Foundations of Management, Vol. 8, str. 167- 174.

${ }^{39}$ Kaynak S., Altuntas S. i Dereli T. (2017). Comparing the innovation performance of EU candidate countries: an entropy-based TOPSIS approach. Economic Research-Ekonomska Istraživanja, 30:1, 31-54.

${ }^{40}$ Bilas V., Bošnjak M. i Novak I. (2019). Inovacijska izvedba zemalja članica Europske unije. Oeconomica Jadertina 1/2019, str. 34-44.
} 
input je ustvari infrastruktura koja omogućava inovacije, razvija inovacijsku kulturu i podstiče inovativno ponašanje. Tu spadaju: institucije, ljudski kapital i istraživanje, infrastruktura, sofisticiranost tržišta, te poslovna sofisticiranost. Krajnji rezultat inovacija predstavljen je u inovacijskom outputu, koji obuhvata dva podindeksa: outputi znanja i tehnologija i kreativni outputi. Suština izvještaja ogleda se u rangiranju inovacijskih sposobnosti i rezultata svjetskih privreda, te u prikazu snaga i slabosti određene zemlje. GII omogućava privredama da analiziraju svoje inovacijske učinke, kreiraju odgovarajuće inovacione politike i odrede prioritete u poduzimanju mjera za jačanje inovativne aktivnosti. Pored toga djeluje i proaktivno, npr. GII 2020 istražuje nove metode finansiranja inovacija u svijetu nakon COVID-a, koje su nužno potrebne u trenutku u kojem je svjetska privredna situacija značajno otežana posljedicama globalne pandemije.

Indeks globalne konkurentnosti razvijen od stane Svjetskog ekonomskog foruma (WEF - World Economic Forum) koristi se za rangiranje zemalja na temelju analize 12 stubova konkurentnosti grupiranih u tri podindeksa (osnovni faktori, faktori povećanja efikasnosti i faktori inovacija i sofisticiranosti). Zemlje čija je ekonomija bazirana na osnovnim faktorima prema indeksu globalne konkurentnosti se nalaze na prvom nivou razvoja. Održavanje konkurentnosti na ovom nivou razvoja zavisi prvenstveno od dobro funkcionirajućih javnih i privatnih institucija (1. stub), dobro razvijene infrastrukture (2. stub), stabilnog makroekonomskog okruženja (3. stub) i zdrave radne snage koja je stekla najmanje osnovno obrazovanje (stub 4). Na drugom nivou razvoja se nalaze zemlje koje ostvaruju efikasnije proizvodne procese i rastući kvalitet proizvoda. U ovoj fazi na rast konkurentnosti utiču visoko obrazovanje i stručne obuke (stub 5), efikasno tržište roba (stub 6), efikasno tržište rada (stub 7), razvijeno finansijsko tržište (stub 8), tehnološka spremnost (stub 9) i veličina tržišta (stub 10). Konačno, na trećem nivou su zemlje čija je ekonomija bazirana na inovacijama ili brzom usvajanju inovativnih tehnologija. Na ovom nivou rast konkurentnosti je uslovljen faktorima visoke poslovne sofisticiranosti (11. stub) i inovacijama (12. stub). Postoje i grupe zemalja koje su u tranziciji između prvog i drugog, odnosno drugog i trećeg nivoa. Bosna i Hercegovina se već godinama nalazi u grupi zemalja čija je ekonomija bazirana na efikasnosti, zajedno sa Albanijom, Sjevernom Makedonijom, Crnom Gorom i Srbijom. Od zemalja u regionu jedino se 
Hrvatska nalazi u grupi zemalja koje su u tranziciji od ekonomije bazirane na efikasnosti do ekonomije bazirane na inovacijama. ${ }^{41}$

Inače, mjerenjem konkurentnosti nacionalnih ekonomija bavi se Svjetski ekonomski forum (World Economic Forum) od 1979. godine i izdaje godišnji Izvještaj o globalnoj konkurentnosti. Posljednja promjena metodologije sprovedena je tokom 2018. godine, kada je uveden novi način obračuna indeksa GCI 4.0 i prema istom je urađen Izvještaj o globalnoj konkurentnosti za 2019. godinu. Stoga će se za provođenje analize uticaja inovativnosti na konkurentnost izabranih zemalja u empirijskom dijelu koristiti GII za period 2008-2018. godina. ${ }^{42}$

\section{Rezultati empirijskog istraživanja}

U skladu s postavljenim ciljevima istraživanja urađena je komparativna analiza globalnog indexa inovacija (GII), indeksa inovacijskog inputa (IIIInnovation Input Index), indeksa inovacijskog outputa (IOI-Innovation Output Index), ukupno i prema sedam varijabli koje su navedene u odjeljku $2.3 .{ }^{43} \mathrm{Na}$ Slici br. 1 dat je prikaz navedenih varijabli za BiH, zemlje zapadnog Balkana (Albanija, BiH, Crna Gora, Sjeverna Makedonija i Srbija) i izabrane zemlje EU i to: Austrija, Bugarska, Grčka, Hrvatska, Mađarska, Njemačka, Rumunija i Slovenija. Potom je urađena regresiono-korelaciona analiza između inovacijskih inputa i inovacijskih outputa, ${ }^{44}$ te regresiono-korelaciona analiza između inovativnosti i globalne konkurentnosti. Cilj je bio ispitati povezanost između inovativnih aktivnosti i konkurentnosti privrede, kao i između izdataka za istraživanje i razvoj i konkurentnosti privrede.

\footnotetext{
${ }^{41}$ CPU-Centre for Policy and Gouvernance (Centar za politike i upravljanje) Konkurentnost ekonomije u BiH i regionu 2014-2018. http://www.cpu.org.ba/media/35585/Konkurentnostekonomije-u-BiH-i-regionu-2014-2018.pdf

${ }^{42} \mathrm{https}: / /$ tcdata360.worldbank.org/indicators/gci?indicator $=632 \& v i z=$ ine_chart\&years $=200$ 7,2017\&indicators $=944$

${ }^{43} \mathrm{https}$ ://www.globalinnovationindex.org/analysis-indicator

${ }^{44}$ Cvetanović S., Despotović D., Mladenović I. i Jovović D. (2014). The analysis of innovation in Western Balkan countries in 2012. Economic Research-Ekonomska Istraživanja, 27:1, $830-846$.
} 


\subsection{Komparativna analiza inovacijskih performansi $\mathrm{BiH}$ i izabranih zemalja}

Na temelju podataka o vrijednostima GII, III, IOI, kao i njihovih osnovnih komponenti za Bosnu i Hercegovinu, zemlje zapadnog Balkana i odabrane zemlje članice EU, urađen je grafički prikaz, tj. slika br. 1. Riječ je o prikazu odnosa između analiziranih varijabli inovativnosti, koje odslikavaju inovativnost izabranih zemalja.

Slika br. 1 Komparativna analiza varijabli inovativnosti

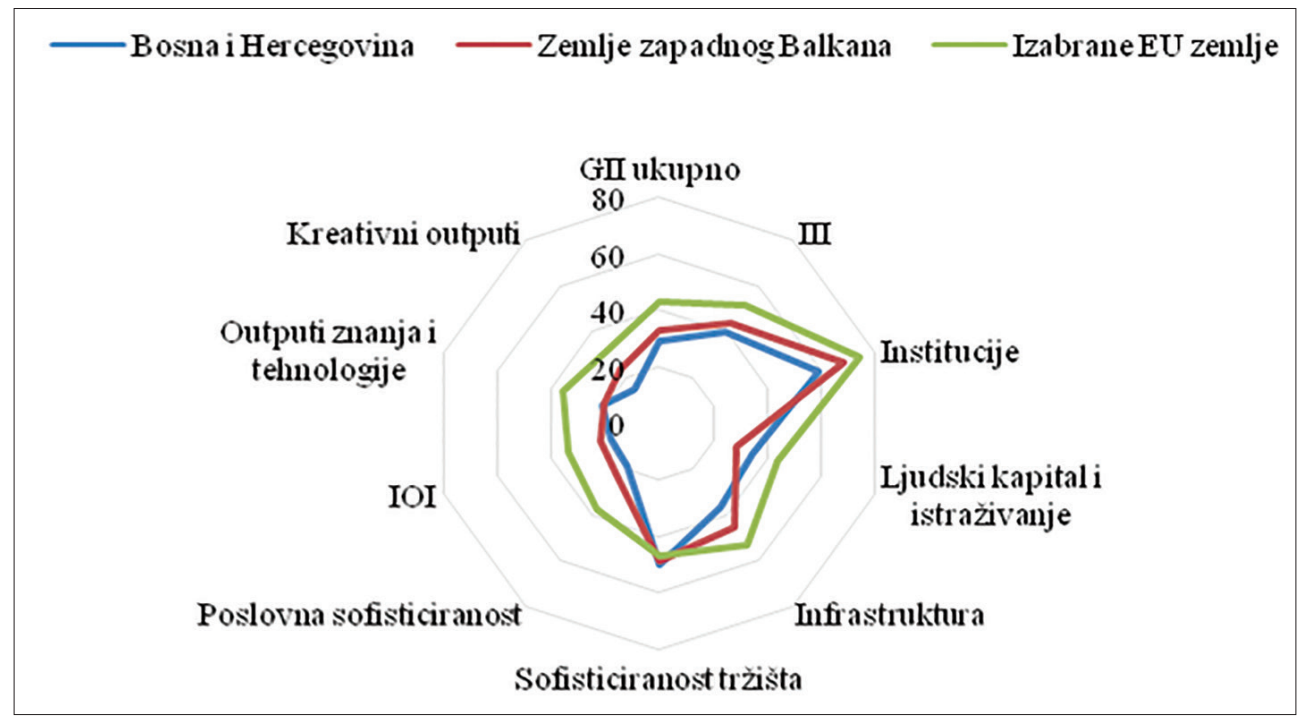

Izvor: Kalkulacija autora na bazi podataka Gll za 2020. godinu

https://www.globalinnovationindex.org/analysis-indicator

Jasno su uočljive razlike, tj. niže vrijednosti u inovacijskim performansama između $\mathrm{BiH}$, zemalja zapadnog Balkana i odabranih zemalja članica EU uz izuzetak dimenzije sofisticiranost tržišta. BiH ima visoke rezultate u odnosu na zemlje regiona u dimenziji ljudski kapital i istraživanje, te je neznatno bolja u dimenzijama sofisticiranost tržišta i rezultati znanja i tehnologije.

Prema Izvještaju globalnog indeksa inovacija za 2020 godinu Bosna i Hercegovina je zauzela 74. mjesto od 131 zemlje, dok je u 2019. godini bila na 76. mjestu. Indeks globalnih inovacija (GII) kao relativne prednosti navodi slijedeća područja u 2020. godini: ljudski kapital, sofisticiranost tržišta, rezultati znanja i tehnologije. Bosna i Hercegovina postiže rezultate ispod prosjeka za svoju dohodovnu grupu, u četiri stuba: institucije, infrastruktura, poslovna sofisticiranost i kreativni rezultati. Još preciznije možemo navesti 
neke identifikovane posebno izražene slabosti u kontekstu našeg istraživanja, a to su: jednostavnost u pokretanju posla (130. mjesto), inovacijske veze (123. mjesto); apsorpcija znanja (128), univerzitetska i industrijska saradnja u istraživanju (124).

\subsection{Korelaciona analiza indeksa inovativnosti i konkurentnosti}

Pored komparativne analize varijabli inovativnosti, urađene su i regresionokorelacione analize i to: analiza veze, odnosa između varijabli III (Innovation Input Index) kao nezavisne varijable i IOI (Innovation Output Index) kao zavisne varijable za zemlje zapadnog Balkana i za izabrane zemlje članice EU u 2020-oj godini, te analiza odnosa inovativnosti i konkurentnosti (GII kao nezavisne varijable i GCI kao zavisne varijable). Standardni način prikazivanja odnosa između dvije varijable je dijagram rasipanja. Uz dijagram rasipanja na slikama su prezentirani i rezultati regresiono-korelacionih linearnih modela. Reprezentativnost regresionih modela izražena je koeficijentom determinacije $\left(R^{2}\right)$ i na osnovu vrijednosti koeficijenta determinacije interpretirana je jačina linearne veze prezentirane kroz regresione modele (kao udio objašnjenog varijabiliteta, nastalog pod uticajem nezavisne varijable, u ukupnom varijabilitetu zavisne varijable).

Slika br. 2 Dijagram rasipanja i regresiono-korelacioni model za III i IOI za zemlje zapadnog Balkana i izabrane EU zemlje

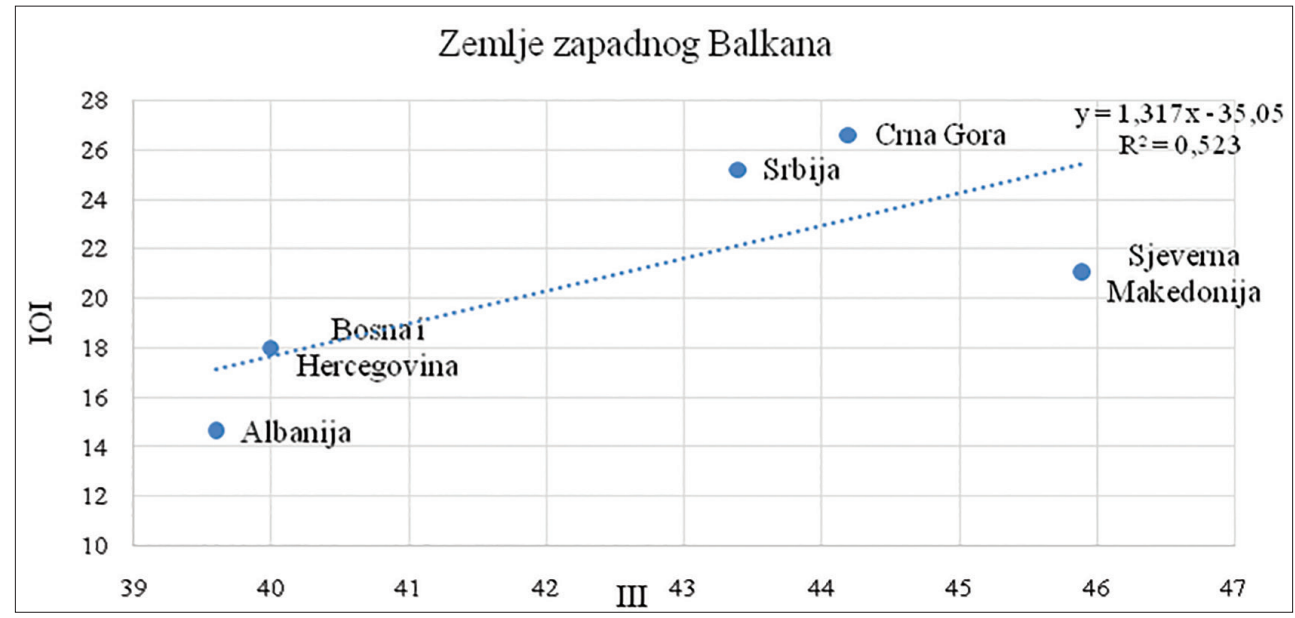




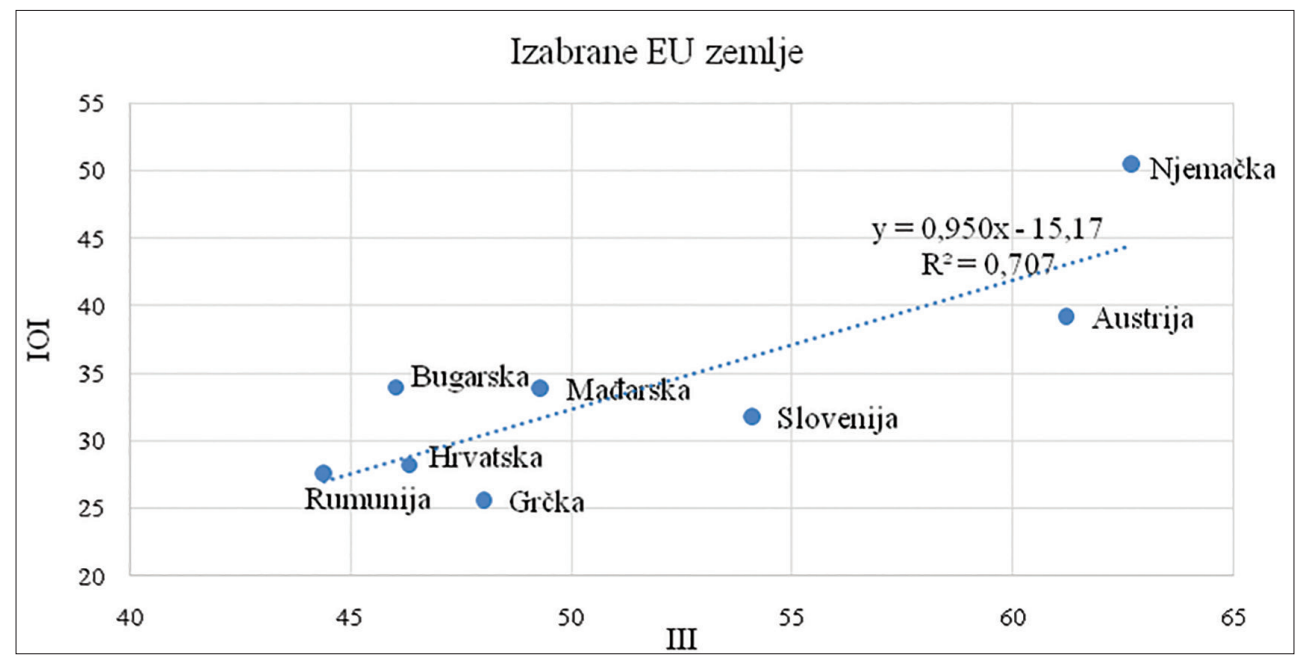

Izvor: Kalkulacija autora na bazi podataka GII za 2020. godinu

https://www.globalinnovationindex.org/analysis-indicator

Slika br. 2 prikazuje dva zasebna dijagrama rasipanja između varijabli III i IOI i to za zemlje zapadnog Balkana i za izabrane zemlje članice EU. Linearni model ukazuje na vezu osrednje jačine (52,3\%) u zemljama zapadnog Balkana dok kod izabranih EU zemalja isti model ukazuje na statistički značajniju vezu između III i IOI, jačine $70,7 \%$.

Da bismo došli do odgovora u kojoj mjeri inovativnost utiče na konkurentnost izabranih zemalja, odnosno utvrdili jačinu veze između inovativnosti i konkurentnosti koristili smo podatke iz Izvještaja za GII iz 2017. godine i za GCI iz 2018. godine. Smatrali smo neopravdanim uzeti pokazatelje iz iste godine, jer je za očekivati da inovativne i istraživačko-razvojne aktivnosti mogu doprinijeti konkurentnosti zemlje najbrže moguće tek naredne godine.

$\mathrm{Na}$ Slici br. 3 dat je prikaz parova podataka varijabli GII i GCI ${ }^{45}$ za zemlje zapadnog Balkana i odabrane zemlje EU. Očito je da kod odabranih zemalja EU postoji snažna direktna linearna korelacija, kao i statistički signifikantan uticaj GII na GCI (97,3\%). S druge strane, analiza odnosa između GII i GCI na nivou zapadnog Balkana bez Sjeverne Makedonije ${ }^{46}$ je pokazala da, prema linearnom modelu, ne postoji statistički značajan uticaj GII na GCI $(11,2 \%)$.

\footnotetext{
${ }^{45}$ https://govdata360.worldbank.org/indicators/ha03bec65?indicator=41619\&viz=line_chart\& years $=2017,2019$

${ }^{46}$ Napomena: nije bilo podataka za Sjevernu Makedoniju za GCI za 2018. godinu.
} 
Posebna izdanja ANUBiH CC, ODN knjiga 18, str. 119-141

Slika br. 3 Dijagram rasipanja i regresiono-korelacioni model za GII i GCI za zemlje zapadnog Balkana i izabrane EU zemlje
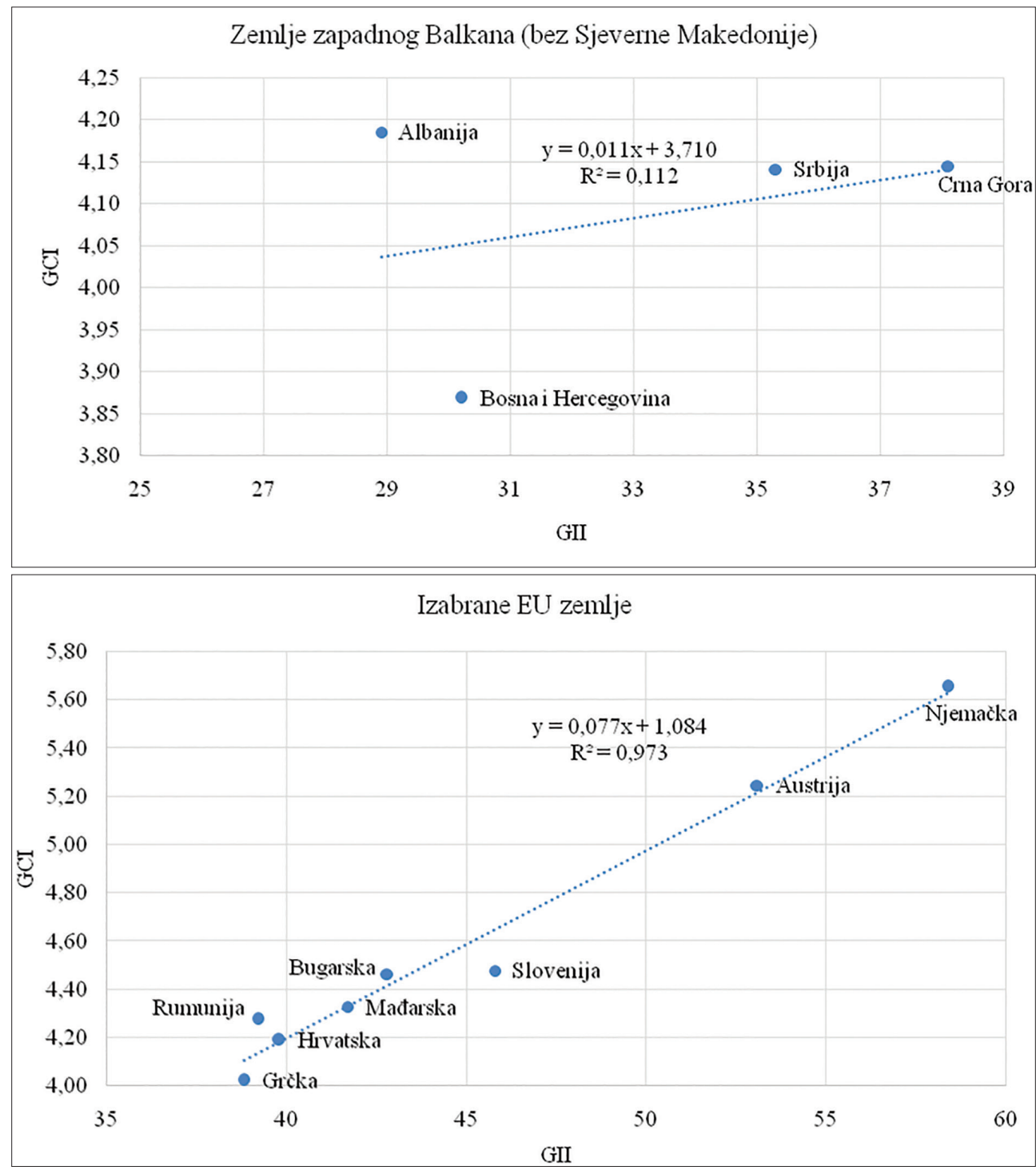

Izvor: Kalkulacija autora na bazi podataka GII za 2017.i GCl za 2018. godinu https://www.globalinnovationindex.org/analysis-indicator i https://tcdata360.worldbank.org/indicators/gci?indicator=632\&viz=line_chart\&years=2007,2017\&indicators=944

S ciljem pronalaženja odgovora na izuzetno slab uticaj varijabli inovativnosti na konkurentnost kod zemalja zapadnog Balkana, u nastavku smo analizirali određene varijable iz GCI za period 2008-2018. za sve odabrane zemlje i to 12. stub - inovacije, te varijable koje se odnose na izdatke kompanija za istraživanje i razvoj, sposobnost za inovacije i saradnju univerziteta i 
industrije u istraživanju i razvoju. Za sve navedene varijable daleko veće vrijednosti i bolja rangiranja imaju odabrane zemlje članice EU, u prvom redu Njemačka i Austrija. Primjera radi, najveći izdaci za istraživanje i razvoj, prikazano \% GDP za 2018. godinu su zabilježeni u Austriji $(3,17 \%)$ i Njemačkoj (3,09\%), dok između 1 i 2\% GDP izdvajaju Slovenija (1,94\%), Mađarska $(1,55 \%)$ i Grčka (1,18\%). Najniži izdaci su zabilježeni u BiH $(0,20 \%)$, potom slijede Crna Gora (0,37\%), Rumunija (0,51\%), Bugarska (0,77\%), Srbija $(0,92 \%)$ i Hrvatska $(0,97 \%) .{ }^{47}$

Ipak, rezultati analize prosječne godišnje stope promjene tokom deset godina pokazuju različitu brzinu kretanja prethodno predstavljenih varijabli. Najbrži porast GCI su ostvarile Albanija i Sjeverna Makedonija, u prosjeku vrijednost indeksa godišnje je rasla 1,85\% odnosno 1,39\%, dok je kod Grčke, Hrvatske, Mađarske i Slovenije evidentan blaži pad indeksa. Kod BIH GCI u prosjeku godišnje raste po stopi od $0,96 \%$. Slična situacija je kod 12 . stuba, inovacija, gdje je najbrži rast ostvarila Albanija 4,30\% dok je $\mathrm{BiH}$ postigla prosječni godišnji rast od $0,81 \%$. Odgovor se dobrim dijelom može naći i u strukturi izvoza i strukturi privredne djelatnosti, odnosno zastupljenosti određenih industrija u zapošljavanju i ostvarenom prometu. ${ }^{48}$

Za dobijanje sveobuhvatnije slike o ulozi kompanija u funkcionisanju inovacionog sistema, analizirali smo statističke podatke za Bosnu i Hercegovinu i to: bruto domaće izdatke za IiR, udio ukupnih bruto domaćih izdataka za istraživanje i razvoj u GDP, broj zaposlenih na poslovima istraživanja i razvoja, broj objavljenih istraživačkih radova i broj jedinica koje se bave istraživanjem i razvojem za period 2012-2019. godina. Naš fokus je bio na pokazateljima vezanim za poslovni sektor u odnosu na državni sektor, visoko obrazovanje i neprofitni sektor. Primjetna je dominantna zastupljenost zaposlenih na poslovima istraživanja i razvoja u visokom obrazovanju u odnosu na poslovni sektor, dok je manja zastupljenost u državnom i neznatna u neprofitnom sektoru. Prema broju objavljenih istraživačkih radova takođe dominira visoko obrazovanje u odnosu na ostale posmatrane sektore, dok je kod broja jedinica koje se bave istraživanjem i razvojem manja razlika između sektora, ali i dalje na prvom mjestu je visoko obrazovanje. Prema istraživanju

\footnotetext{
${ }^{47} \mathrm{https}$ ://tcdata360.worldbank.org/indicators/GB.XPD.RSDV.GD.ZS? indicator=2013\&viz= line_chart\&years=1996,2017

uz napomenu da nisu bili raspoloživi podaci za Albaniju i Sjevernu Makedoniju.

${ }^{48}$ Matusiak M. i Kleibrink A. (ed.) (2018). Supporting an Innovation Agenda for the Western Balkans: Tools and Methodologies. Publications Office of the European Union, Luxembourg, doi:10.2760/48162, JRC111430.
} 
inovativnih aktivnosti preduzeća u Bosni i Hercegovini, koje je provedeno na uzorku od 3.116 preduzeća za period 2016-2018. godina 35,6\% je provelo bar jednu inovativnu aktivnost, dok $64,4 \%$ preduzeća nije provodilo inovativne aktivnosti. ${ }^{49}$

Posebno interesantno je analizirati izdatke za IiR, gdje ponovo dominira visoko obrazovanje u odnosu na poslovni sektor, a potom slijede državni i neprofitni sektor. Ukupni bruto domaći izdaci za istraživanje i razvoj u BDP se kreću oko 0,20\% u periodu 2015-2019. godina. Od toga je polovina usmjerena na IiR u visokom obrazovanju. Slične podatke nalazimo i u Izvještaju Evropske komisije i to da je procijenjeni ukupni iznos sredstava koja zemlja odvaja za istraživanja još nizak, na nivou od $0,3 \%$ BDP-a. Nije postignut napredak u obezbjeđivanju pouzdanih i sveobuhvatnih statističkih podataka o istraživanjima i inovacijama. ${ }^{50}$ Inače, budžetska sredstva institucija koje finansiraju aktivnosti istraživanja i razvoja su namijenjena najviše sektoru visokog obrazovanja 91,4\%, zatim slijedi državni sektor sa namijenjenih $6,6 \%$ budžetskih sredstava. Ostala budžetska sredstva su namijenjena neprofitnom sektoru $1,6 \%$ i poslovnom sektoru $0,5 \% .{ }^{51}$

U narednoj Tabeli su prikazani svi prethodno obrađeni indeksi (GII, GCI i GCI lag ${ }^{52}$ ) i pokazatelji izdvajanja za IiR za Bosnu i Hercegovinu s ciljem utvrđivanja koeficijenta korelacije.

Tabela br. 1 Prikaz GII, GCI i ukupnih bruto domaćih izdataka za IiR u BiH

\begin{tabular}{lllllll}
\hline varijabla/godine & 2013 & 2014 & 2015 & 2016 & 2017 & 2018 \\
\hline GCl BiH & 3,93 & 4,02 & & 3,71 & 3,80 & 3,87 \\
\hline $\begin{array}{l}\text { Ukupno bruto domaći izdaci za } \\
\text { liR u BiH, u KM }\end{array}$ & 86.046 .335 & 70.381 .152 & 62.494 .336 & 64.576 .461 & 62.904 .269 & 65.164 .302 \\
\hline Gll BiH & 36,2 & 32,4 & 32,3 & 29,6 & 30,2 & 31,1 \\
\hline GCl BiH lag & 4,02 & & 3,71 & 3,80 & 3,87 & \\
\hline
\end{tabular}

Izvor: Kalkulacija autora

${ }^{49}$ Agencija za statistiku Bosne i Hercegovine (2020). Nauka, tehnologija i inovacije - Inovativne aktivnosti preduzeća, 2016-2018, Godina IV, broj 1, Sarajevo, 30. 4. 2020.

https://bhas.gov.ba/data/Publikacije/Saopstenja/2020/RDE_04_2016_Y2_0_BS.pdf

${ }^{50}$ Izvještaj o Bosni i Hercegovini za 2020, Saopštenje o politici proširenja EU-a za 2020. Evropska komisija, Brisel 6. 10. 2020, nezvanični prevod.

https://europa.ba/wp-content/uploads/2020/10/Izvjestaj_za_BiH_za_2020_godinu.pdf, str. 92.

${ }^{51}$ Agencija za statistiku Bosne i Hercegovine (2020). Nauka, tehnologija i inovacije - budžetska izdvajanja za istraživanje i razvoj, 2019.-2020., Godina VI, broj 1, Sarajevo, 21. 12. 2020. https://bhas.gov.ba/data/Publikacije/Saopstenja/2020/RDE_03_2019_Y2_0_BS.pdf

${ }^{52}$ Objašnjenje za GCI lag - u odnos su stavljani podaci visine izdataka za IiR iz jedne godine i GCI naredne godine, npr. izdaci iz 2017. a GCI iz 2018. godine. 
Koeficijent linearne korelacije između izdataka za IiR i GCI iznosi 0,8673 što znači da je veza između izdataka za $\mathrm{IiR}^{53}$ i GCI za BiH u posmatranom periodu 2013-2018. godina direktna jačine 86,73\%. Sličnost je primjetna i kod koeficijenta korelacije GII sa GCI koji iznosi 0,6381, a znači da je veza između GII i GCI za BiH u posmatranom periodu direktna jačine 63,81\%. Možemo zaključiti da su oba koeficijenta korelacije visoki odnosno relativno visoki što znači da postoji statistički značajna veza između izdataka za IiR i GCI, te da izdaci za IiR utiču na vrijednost indeksa konkurentnosti. Nešto slabija veza između GII i GCI u odnosu na vezu IiR i GCI ukazuje da globalni indeks inovacija uključuje više komponenti, te bi dublja analiza uzroka ovih odstupanja bila korisna $\mathrm{i}$ interesantna.

\section{Zaključak}

Inovacije i znanje u današnjem dinamičnom i nadasve neizvjesnom poslovnom okruženju predstavljaju ključne faktore za postizanje i očuvanje konkurentnosti kako kompanija tako i nacionalne privrede. Najrazvijenije zemlje današnjice svoj uspjeh su ostvarile upravo prelaskom sa kapitalom intenzivne na znanjem intenzivnu ekonomiju. Jedan od stubova ekonomije znanja jeste efektivan inovacioni sistem u kojem posebno mjesto i ulogu imaju kompanije, odnosno privredni subjekti. Jačanjem svojih istraživačko razvojnih aktivnosti i inovativnih sposobnosti kompanije doprinose oblikovanju i funkcionisanju inovacionog sistema. Međutim, istraživačko-razvojna aktivnost jednog preduzeća ne zavisi samo od njegovih sposobnosti nego i od faktora iz eksternog okruženja, kao što su stav vlade prema naučno istraživačkoj djelatnosti, veza između naučno-istraživačkih institucija (univerziteta i instituta) sa privrednim subjektima, brzina tehnološkog transfera i stopa zastarjevanja znanja. Samo koordinacijom aktivnosti poslovne i akademske zajednice i lokalne vlade, tj. primjenom Triple Helix modela mogu se postići sinergetski efekti i stvoriti veće vrijednosti.

Efekti inovativne aktivnosti na konkurentnost zemalja istraživani su primjenom globalnog indeksa inovacija (GII) i indeksa globalne konkurentnosti (GCI) i to na primjeru Bosne i Hercegovine, zemalja zapadnog Balkana i izabranih zemalja članica EU. Istovremeno, analiza doprinosi procjeni kvalitete njihovih nacionalnih inovacionih sistema. Na temelju provedenih analiza može se zaključiti da BiH i zemlje Zapadnog Balkana postižu niže

53 https://bhas.gov.ba/data/Publikacije/Saopstenja/2020/RDE_03_2019_Y2_0_BS.pdf budžetska izdvajanja za istraživanje i razvoj, 2019-2020. 
vrijednosti u inovacijskim performansama i to posmatrano za ukupni GII, potom III (indeks inovacijskog inputa) i IOI (indeks inovacijskog outputa). Od sedam varijabli globalnog indeksa inovacija za 2020. godinu, izuzetak predstavlja dimenzija sofisticiranost tržišta gdje zemlje zapadnog Balkana ne zaostaju (npr. za BiH vrijednost ove varijable je 50,1 a kod Austrije je 51,1). Međutim, vrijednost GII za BiH je 29, u poređenju sa ostalim posmatranim zemljama samo kod Albanije je niža vrijednost globalnog indeksa inovacija $(27,1)$. Najveće vrijednosti GII u 2020. godini bilježe Njemačka 56,5 a slijede je Austrija $(50,1)$ i Slovenija $(42,9)$.

Slijedeći zaključci su rezultat analize korelacije između III i IOI na nivou zemalja zapadnog Balkana i na nivou izabranih zemalja EU. Linearnim modelom utvrđeno je postojanje veze osrednje jačine $(52,3 \%)$ u zemljama zapadnog Balkana dok kod izabranih EU zemalja isti model ukazuje na statistički značajniju vezu između III i IOI, jačine 70,7\%. U procesu analize korelacije između GII za 2017. godinu i GCI za 2018. godinu utvrdili smo kod odabranih zemalja EU snažnu direktnu linearnu korelaciju, kao i statistički signifikantan uticaj GII na GCI (97,3\%), dok na nivou zemalja zapadnog Balkana ne postoji statistički značajan uticaj GII na GCI $(11,2 \%)$. Kao uzroci izuzetno slabog uticaja varijabli inovativnosti na konkurentnost zemalja zapadnog Balkana mogu se posebno istaći izdaci za istraživanje i razvoj (\% GDP) i izdvajanje kompanija za istraživanje i razvoj. Doprinos kompanija funkcionisanju inovacionog sistema može se pratiti i prema broju zaposlenih istraživača, broju istraživačkih jedinica i broju objavljenih radova. Ovi pokazatelji su predstavljeni za Bosnu i Hercegovinu, urađena je korelaciona analiza između izdataka za IiR i GCI, kao i između GII i GCI, te je utvrđeno postojanje statistički značajne veze između izdataka za IiR i GCI, kao i između GII i GCI.

Na temelju izloženog možemo zaključiti da se ne mogu očekivati visoke inovacijske performanse $u$ privredi s malim postotkom izdataka za istraživanje i razvoj, te da niska inovativnost predstavlja ograničavajući faktor konkurentnosti. Stoga kompanije trebaju razvijati inovativne sposobnosti, podsticati istraživačko razvojne aktivnosti i kontinuirano učenje. Takvim, proaktivnim pristupom i intenzivnom saradnjom sa naučno-istraživačkim institucijama, uz podršku vlade doprinose efektivnom i efikasnom funkcionisanju inovacionih sistema, konkurentnosti privrede i dugoročnom ekonomskom i socijalnom razvoju. 


\section{Literatura}

1. Adam F. (2014). Measuring National InnovationPerformance - the Innovation Union Scoreboard Revisited. Springer. Berlin, Heidelberg.

2. Agencija za statistiku Bosne i Hercegovine (2020). Nauka, tehnologija i inovacije - Patenti 2019, Godina VI, broj 1, Sarajevo, 15. 10. 2020, https://bhas.gov.ba/data/Publikacije/ Saopstenja/2020/RDE_02_2019_Y1_0_BS.pdf

3. Agencija za statistiku Bosne i Hercegovine (2020). Nauka, tehnologija i inovacije budžetska izdvajanja za istraživanje i razvoj, 2019.-2020., Godina VI, broj 1, Sarajevo, 21. 12. 2020, https://bhas.gov.ba/data/Publikacije/Saopstenja/2020/RDE_03_2019_Y2_0_BS.pdf

4. Agencija za statistiku Bosne i Hercegovine (2020). Nauka, tehnologija i inovacije - Inovativne aktivnosti preduzeća, 2016-2018, Godina IV, broj 1, Sarajevo, 30. 4. 2020.

5. Bilas V., Bošnjak M. i Novak I. (2019). Inovacijska izvedba zemalja članica Europske unije. Oeconomica Jadertina 1/2019, str. 34-44.

6. Chaminade, C. i Lundvall B. (2019). Science, Technology, and Innovation Policy:Old Patterns and New Challenges. Oxford University Press. Oxford.

7. Chuvakhina L.G., Terskaya G.A. i Buevich S.Y.(2018). Innovations as a factor of state's improved performance in the World Economic System. Revista Espacios, Vol. 39 (\# 04) Year 2018.

8. CPU-Centre for Policy and Gouvernance. Konkurentnost ekonomije u BiH i regionu 2014-2018. http://www.cpu.org.ba/media/35585/Konkurentnost-ekonomije-u-BiH-i-regionu-2014-2018.pdf (pristup 15. 6. 2021. godine)

9. Cvetanovic D., Cvetanović S. i Bogić D. (2020). Rastući značaj koncepta regionalnih inovacionih sistema za ekonomski i društveni razvoj, https://konferencija.komorapirot.com/44.RASTUCI\%20ZNACAJ\%20KONCEPTA $\% 20$ REGIONALNIH\%20INOVACIONIH\%20SISTEMA\%20ZA\%20EKONOMSKI\%20 I\%20DRUSTVENI\%20RAZVOJ.pdf. (pristup 11. 6. 2021. godine)

10. Cvetanović S., Despotović D., Mladenović I. i Jovović D. (2014). The analysis of innovation in Western Balkan countries in 2012. Economic Research-Ekonomska Istraživanja, 27:1, 830-846, DOI: 10.1080/1331677X.2014.974920

11. Despotović D. i Cvetanović S. (2017). The theoretical explication of the factors of regional growth and the economic convergence (divergence) of the region. Economic Horizons, May - August 2017, Volume 19, Number 2, 111 - 125.

12. Dossou Y.L. i Khvatova T.Y. (2020). Analysis of innovative activity of companies in developing countries on the example of West African countries. St. Petersburg State Polytechnical University Journal. Economics, 13 (1) (2020) 79-90. DOI: 10.18721/JE.13107

13. European Commision (2020). Science, research and Innovation Performance of the EU 2020, A fair, green and digital Europe. Publication Office of the European Union. Luxembourg. https://ec.europa.eu/info/publications/science-research-and-innovation-performance-eu-2020_en. (pristup 11.6.2021. godine)

14. Fatma A. (2018). Overview of the Japanese Innovation Systems vs. the American Innovation System. Journal of Global Economics, 6: 312. doi:10.4172/2375-4389.1000312

15. Freeman, C. (1995). The "National System of Innovation" in historical perspective. Cambridge Journal of Economics, 19 (1) 5-24.

16. Gogodze J. (2016). Mechanisms and Functions within a National Innovation System. Journal of Technology Management\&Innovation, Universidad Alberto Hurtado, Facultad de Economía y Negocios. Volume 11, Issue 4, str. 12-21. 
17. Hetze P. i Meyer M. (2018). Was bringt die Oeffnung von Wissenschaft und Innovation? Stifterverband Bildung. Wissenschaft.Innovation, Berlin.

18. http://ec.europa.eu/europe2020/index_en.htm, (pristup 10.6.2021.godine)

19. https://tcdata360.worldbank.org/indicators/GB.XPD.RSDV.GD.ZS?indicator=2013 \&viz=line_chart\&years $=1996,2017$, (pristup 10. 6. 2021. godine)

20. https://bhas.gov.ba/data/Publikacije/Saopstenja/2020/RDE_03_2019_Y2_0_BS.pdf

21.https://bhas.gov.ba/data/Publikacije/Saopstenja/2020/RDE_04_2016_Y2_0_BS.pdf

22. https://ec.europa.eu/info/research-and-innovation/research-area/industrial-research-andinnovation_en, (pristup 10.6.2021. godine)

23. https://govdata360. worldbank.org/indicators/ha03bec65? indicator $=41619 \& v i z=$ line chart\&years $=2017,2019$, (pristup 10. 6. 2021. godine)

24. https://tcdata360.worldbank.org/indicators/gci?indicator $=632 \&$ viz=line_chart\&years $=2$ 007,2017\&indicators $=944$, (pristup 10.6.2021. godine)

25. https://www.globalinnovationindex.org/analysis-indicator, (pristup 10. 06. 2021. godine)

26. Izvještaj o Bosni i Hercegovini za 2020, Saopštenje o politici proširenja EU-a za 2020. Evropska komisija. Brisel 6. 10. 2020, nezvanični prevod, https://europa.ba/wp-content/ uploads/2020/10/Izvjestaj_za_BiH_za_2020_godinu.pdf (pristup 11. 06. 2021.)

27. Jankowska B., Matysek-Jędrych A. i Mroczek-Dąbrowska, K. (2017). Efficiency of national innovation systems: Poland and Bulgaria in the context of the Global Innovation Index. Comparative Economic Research, De Gruyter, Warsaw, Vol. 20, Iss. 3, pp. 77-94.

28. Ješić J. (2015). Model četverostruke spirale (Quadruple Helix Model) kao osnova nacionalnog inovacionog sistema. Doktorska teza. Univerzitet Edukons Fakultet poslovne ekonomije Sremska Kamenica, Novi Sad.

29. Jovičić J. i Petković S. (2016). Inovacije kao faktor konkurentnosti privrede s osvrtom na Bosnu i Hercegovinu. Obrazovanje za preduzetništvo, 6(1), str. 99-110.

30. Kaynak S., Altuntas S. i Dereli T. (2017). Comparing the innovation performance of EU candidate countries: an entropy-based TOPSIS approach. Economic Research-Ekonomska Istraživanja, 30:1, 31-54, DOI: 10.1080/1331677X.2016.1265895

31. Leydesdorff L. i Strand Ø. (2013). The Swedish System of Innovation: Regional Synergies in a Knowledge-Based Economy. Journal of the American Society for Information Science and Technology, DOI: 10.1002/asi.22895

32. Mandić S. i Trivunović D. (2020). Analiza konkurentnosti ekonomije Bosne i Hercegovine. Jahorina Business Forum 2020, str. 511-520.

33. Melaas A. i Zhang F. (2016). National Innovation Systems in the United States and China A Brief Review of the Literature. The Center for International Environment\&Resource Policy, Tufs University. Medford.

34. Mosurović Ružičić M., Miletić M. i Dobrota, M. (2021). Does a National Innovation System Encourage Sustainability? Lessons from the Construction Industry in Serbia. Sustainability 2021, 13, 3591. https://doi.org/10.3390/su13073591

35. OECD (2013). Triple Helix partnerstva za inovacije u Bosni i Hercegovini. Razvoj privatnog sektora - Priručnik za politike, Sarajevo.

36. OECD (2005). Oslo Manual: Guidelines for collecting and interpreting innovation data. 3. izdanje, OECD, Pariz.

37. Piljić J. (2018). Analiza konkurentnosti Bosne i Hercegovine i preporuke za jačanje konkurentnosti, Tranzicija/Transition. Časopis za ekonomiju i politiku tranzicije/ Journal of economic and politics of Transition, Godina XX, Vitez-Tuzla- Zagreb-BeogradBukurešt, br. 41. 
38. Polt W., Rammer Ch., Schartinger D., Gassler H. i Schibany A. (2001). Benchmarking Industry-Science Relations in Europe - the Role of Framework Conditions. Science and Public Policy, 28 (4), pages 247-258, August 2001.

39. Porter M. i Stern, S. (2002). National innovative capacity. In K. Scwab, M. Porter, \& J. Sachs (Eds.), The global competitiveness report 2001-2002, 102-118. Oxford University Press. New York.

40. Puljiz J. (2009). Faktori regionalnog razvoja i regionalnih nejednakosti u Republici Hrvatskoj. Doktorska disertacija, Ekonomski fakultet, Sveučilište u Splitu. Split, Republika Hrvatska. https://www.bib.irb.hr/393855

41. Radošević S. (2002). Regional innovation systems in Central and Eastern Europe: Determinants, organizers and alignments. The Journal of Technology Transfer, 27, 87-96.

42. Rahimić Z. (2006). Izgradnja konkurentskih prednosti preduzeća kroz njegova strateška opredjeljenja. Ekonomski fakultet u Sarajevu. Sarajevo.

43. Rahimić Z. i Kožo A. (2009). Building and Development of the Knowledge Based Economy in Bosnia and Herzegovina. Journal of Interdisciplinary Management Research, Vol. V, January 2009, str. 111-122.

44. Rigg C., Coughlan P., O’Leary D. i Coghlan D. (2021). A practice perspective on knowledge, learning and innovation - insights from an EU network of small food producers. Entrepreneurship \& Regional Development, DOI: 10.1080/08985626.2021.1877832

45. Schrempf B., Kaplan D. i Schroeder D. (2013). National, Regional, and Sectoral Systems of Innovation-An overview. Report for FP7 Project "Progress", progressproject.eu. https://www.progressproject.eu/wp-content/uploads/2013/12/Progress_D2.2_final.pdf

46. Sciene, research and Innovation Performance of the EU 2020, A fair, green and digital Europe, European Commission,https://ec.europa.eu/info/publications/science-researchand-innovation-performance-eu-2020_en

47. Trifković M. (2020). Harmonizacija sistema nauke u Bosni i Hercegovini. Akademija nauka i umjetnosti Bosne i Hercegovine, Centar za sistemska istraživanja, knjiga 5/1, posebna izdanja. Sarajevo.

48. Vukotić S., Zakić N. i Ćurčić N. (2017). Menadžment znanja i upravljanje inovacijama kao izvor poslovnog uspeha i konkurentske predosti preduzeća. Četvrti naučno-stručni skup POLITEHNIKA 2017, str. 436-442.

49. Warnke P. et al. (2016). Opening up the innovation system framework towards new actors and institutions. Fraunhofer ISI Discussion Papers - Innovation Systems and Policy Analysis, No. 49, Fraunhofer ISI, Karlsruhe.

50. Wojciech N. (2016). Composite Indexes Economic and Social Performance: Do They Provide Valuable Information. Foundations of Management, Vol. 8, str. 167- 174.

51. Yongabo P. i Göransson B (2020). Constructing the national innovation system in Rwanda: efforts and challenges. Innovation and Development, DOI:10.1080/215793 0X.2020.1846886 